\title{
Spatial and temporal extension of wild fish aggregations at Sparus aurata and Thunnus thynnus farms in the north-western Mediterranean
}

\author{
Kathrin Bacher ${ }^{1, *}$, Ana Gordoa ${ }^{1}$, Oscar Sagué ${ }^{2}$ \\ ${ }^{1}$ Centro de Estudios Avanzados de Blanes (CEAB-CSIC), 17300 Blanes, Spain \\ ${ }^{2}$ Federació Catalana d'Activitats Subaquàtiques, 08930 Sant Adrià del Besòs, Spain
}

\begin{abstract}
Fish farms cause wild fish to aggregate nearby and thus act to modify their distribution, but the spatial and temporal extent of the attraction effect around farms is still poorly understood. We examined attraction using an integrated approach combining 3 factors: spatial extent, depth and season. We analysed an Atlantic bluefin tuna Thunnus thynnus (ABT) and a gilthead seabream Sparus aurata (SB) farm off the north-eastern coast of Spain which represent different fish farming models in the Mediterranean. Underwater visual counts were conducted from summer 2010 to spring 2011. We recorded 39 species at the SB farm and 17 species at the ABT farm. The analysis of fish abundance and biomass at 3 stations located along a distance gradient from the farm (SB: 0, 30, $200 \mathrm{~m}$; ABT: 0, 100, $200 \mathrm{~m}$ ) showed significantly higher values next to the cages than at more distant stations, revealing that the spatial extent of the attraction effect was mainly restricted to the cage rather than following a gradient. The intensity of the cage effect varied according to farm, season and depth, reflecting species-specific behaviours. At the SB farm, the cage effect persisted year round, varying with depth, whereas at the ABT farm, the effect was only detected in summer and spring. These distinct spatial and temporal aggregation patterns suggest that implementation of fishery regulatory measures to protect wild fish should be farm-specific. This study emphasizes the importance of using an integrated approach to study wild fish aggregations at farms.
\end{abstract}

KEY WORDS: Sea-cage $\cdot$ Aquaculture $\cdot$ Wild fish $\cdot$ Attraction effect $\cdot$ Sparus aurata $\cdot$ Thunnus thynnus $\cdot$ Mediterranean

Resale or republication not permitted without written consent of the publisher

\section{INTRODUCTION}

The impact of human activities on marine ecosystems extends around the world. A recent global study revealed that no area is unaffected by human influences and that a considerable proportion $(41 \%)$ is heavily affected by multiple drivers (Halpern et al. 2008). Coastal areas in particular are being impacted by a wide variety of human activities as a consequence of the pressures of population growth (Burbridge 1999). Aquaculture is an activity that has been expanding rapidly in recent years due to the world- wide demand for seafood. This anthropogenic activity generates new feeding grounds for wild fish populations in the littoral zone. Several studies have shown that fish farms attract wild fish in their near vicinity, thereby altering natural distribution patterns (e.g. Carss 1990, Dempster et al. 2002, Boyra et al. 2004). Apart from high food availability, the presence of an artificial structure and the chemical attraction to farmed fish have been put forward as influences contributing to this aggregation effect (Tuya et al. 2006). The physiological consequences of this new food source on local fish populations are still unclear 
(Fernandez-Jover et al. 2011). A recent study has shown that farms do not seem to negatively affect wild fish species like saithe Pollachius virens and Atlantic cod Gadus morhua but rather act to enhance the body condition of farm-associated fish (Dempster et al. 2011). In parallel, consumption of lost food by wild fish may buffer the environmental impact on the benthos underneath farms (e.g. Lupatsch et al. 2003, Vita et al. 2004). Therefore, it has been argued that fish harvesting should be avoided in the vicinity of farms (Dempster et al. 2006), in order to fully benefit from the recycling function of wild fish. However, the spatial extent of fish aggregations around farms has been poorly studied to date. Previous work has examined differences between farms and distant control locations (e.g. Dempster et al. 2002, Boyra et al. 2004) and only recently has the distance factor been examined in the vicinity of Norwegian salmon farms (Dempster et al. 2010).

The natural distribution of fish populations in the littoral zone is influenced by different factors, such as depth (Bell 1983, García-Charton \& Pérez-Ruzafa 1998) and habitat structure (Letourneur et al. 2003, Lombarte et al. 2012), which influence the type and distribution of food and shelter (García-Charton \& Pérez-Ruzafa 2001). Depth has also been identified as an important factor determining spatial patterns of fish aggregations at fish farms (Dempster et al. 2005, Sudirman et al. 2009). In addition, previous studies have shown that the species composition of fish aggregations at farms changes with the season (Valle et al. 2007, Fernandez-Jover et al. 2008), indicating species-specific residence times at farms. Although the spatial and temporal variability of farms has been studied previously, no systematic approach to assess the spatial and temporal extent of the attraction effect has yet been undertaken. An understanding of whether this attraction persists across seasons, how it changes with time, and what spatial distances and depths are reached is essential. Despite the growing number of publications on the variability of wild fish aggregations at fish farms which have taken different factors into account (Table 1), an integrated analysis is currently lacking. This study is intended to begin filling this gap by putting forward a comprehensive approach that analyses and combines the main factors known to influence wild fish aggregations, namely spatial extent, depth and season. Determining these factors has implications for future regulatory measures to be implemented for fish farms. The specific objectives of this study were to examine the horizontal spatial attraction range along a distance gradient away from the farm for each depth, and to investigate temporal variability.

Sampling was carried out at 2 fish farms that represent different fish farming models in the Mediterranean Sea: an Atlantic bluefin tuna Thunnus thynnus (ABT) farm and a gilthead seabream Sparus aurata (SB) farm. Gilthead seabream has been cultured extensively for many years throughout the Mediterranean (FAO 2008), and ABT capture-based aquaculture, known as fattening farms, have developed rapidly and today are present in the waters of 9 Mediterranean countries (see www.ICCAT.int).

Table 1. Summary of studies that have investigated different factors influencing variation in fish aggregations at marine fish farms. Farm types: GR/RA = mixed groupers (Epinephelus fuscoguttatus and Cromileptes altivelis) and rabbitfish Siganus spp., SB/ESB = mixed gilthead seabream Sparus aurata and European seabass Dicentrarchus labrax, WSB = white seabass Atractoscion nobilis, ABT = Atlantic bluefin tuna Thunnus thynnus, AS = Atlantic salmon Salmo salar. Depths: S = surface, M1 = intermediate cage depth, M2 = between the cage and the sea bottom, $\mathrm{AB}=$ above bottom, $\mathrm{B}=$ bottom

\begin{tabular}{|c|c|c|c|c|c|c|c|}
\hline $\begin{array}{l}\text { Study } \\
\text { location }\end{array}$ & $\begin{array}{l}\text { No. } \\
\text { farms }\end{array}$ & Factors & $\begin{array}{l}\text { Farm } \\
\text { type }\end{array}$ & Sampling sites & Sampling depths & $\begin{array}{l}\text { Sampling } \\
\text { period }\end{array}$ & Source \\
\hline Spain & 9 & Distance between farms & $\mathrm{SB} / \mathrm{ESB}$ & Cage, $200 \mathrm{~m}$ & Integrated (5-10 m) & Sep/Oct & Dempster et al. (2002) \\
\hline Spain & 5 & Depth & $\mathrm{SB} / \mathrm{ESB}$ & Cage & $\mathrm{S}, \mathrm{M} 1, \mathrm{M} 2, \mathrm{~B}$ & Oct/Nov & Dempster et al. (2005) \\
\hline Norway & 9 & Depth & AS & Cage, 1-2 km & $\mathrm{S}, \mathrm{M} 1, \mathrm{M} 2, \mathrm{AB}, \mathrm{B}$ & Summer & Dempster et al. (2009) \\
\hline Indonesia & 1 & Depth, time of day & GR/RA & Cage & $1-3,3-6,6-9,>9 \mathrm{~m}$ & Dec-Apr & Sudirman et al. (2009) \\
\hline USA & 1 & Depth, season & WSB & Cage, $200 \mathrm{~m}$ & $\mathrm{~S}, \mathrm{M} 1, \mathrm{~B}$ & $1 \mathrm{yr}$ & Oakes \& Pondella (2009) \\
\hline Spain & 1 & Season & $\mathrm{SB} / \mathrm{ESB}$ & Cage, $200 \mathrm{~m}$ & Integrated (5-10 m) & $1 \mathrm{yr}$ & Valle et al. (2007) \\
\hline Spain & 3 & Season & $\mathrm{SB} / \mathrm{ESB}$ & Cage & Integrated $(5-10 \mathrm{~m})$ & $2 \mathrm{yr}$ & $\begin{array}{l}\text { Fernandez-Jover et al. } \\
(2008)\end{array}$ \\
\hline Canary Isl. & 2 & Seas & $\mathrm{SB} / \mathrm{ESB}$ & Cage, $500 \mathrm{~m}-1 \mathrm{~km}$ & Integ & $1 \mathrm{yr}$ & Boyra et al. (2004) \\
\hline Croatia & 2 & Season & $\mathrm{ABT}$ & Cage, $200 \mathrm{~m}$ & Integrated $(0-15 \mathrm{~m})$ & $1 \mathrm{yr}$ & Šegvić Bubić et al. (2011) \\
\hline Norway & 9 & Spatial extent & AS & Cage, 25, 50, $200 \mathrm{~m}$ & Integrated (5 m-B) & Jul/Oct & Dempster et al. (2010) \\
\hline Spain & 1 & Extent, depth, season & $\mathrm{ABT}$ & Cage, $100,200 \mathrm{~m}$ & $\mathrm{~S}, \mathrm{M} 1, \mathrm{M} 2$ & $1 \mathrm{yr}$ & Present study \\
\hline Spain & 1 & Extent, depth, season & SB & Cage, 30, $200 \mathrm{~m}$ & $\mathrm{~S}, \mathrm{M} 1, \mathrm{~B}$ & $1 \mathrm{yr}$ & Present study \\
\hline
\end{tabular}




\section{MATERIALS AND METHODS}

\section{Study site and farm characteristics}

The selected farms are located in the littoral area influenced by the Ebro River in the north-western Mediterranean Sea (Fig. 1) off their common home port of L'Ametlla de Mar (40 53' 10" N, $\left.0^{\circ} 48^{\prime} 13^{\prime \prime} \mathrm{E}\right)$. The SB farm is located about $1 \mathrm{~km}$ from the coast over a rocky-sandy bottom with a bottom depth of $20 \mathrm{~m}$. The farm started operating in 1993, consists of 30 circular cages (each $19 \mathrm{~m}$ in diameter) with a net depth of $10 \mathrm{~m}$, and covers a leased area of $400000 \mathrm{~m}^{2}$. On average, the farm contains $850 \mathrm{t}$ of stocked fish biomass and produces $800 \mathrm{t}$ of Sparus aurata annually. Farmed fish are fed $2500 \mathrm{t} \mathrm{yr}^{-1}$ of dry food pellets based on fish meal and vegetable oil. The ABT farm is located farther offshore $(4.5 \mathrm{~km})$ over a mixed gravel-mud-sand bottom with a bottom depth of $45 \mathrm{~m}$. The farm started operating in 2004, and the total leased area is $300000 \mathrm{~m}^{2}$. During the study, 2 oval cages (each $120 \times 60 \mathrm{~m}$ ) and 4 round cages (each $50 \mathrm{~m}$ in diameter) with a net depth of $30 \mathrm{~m}$ were in use. On average, the farm stocks $700 \mathrm{t}$ of wild adult Thunnus thynnus caught in the western Mediterranean spawning grounds and reaches an annual production of about $990 \mathrm{t}$. The tunas are exclusively fed with frozen fish $\left(5700 \mathrm{t} \mathrm{yr}^{-1}\right)$ such as Atlantic mackerel Scomber scombrus, round sardinella Sardinella aurita, European pilchard Sardina pilchardus and Atlantic herring Clupea harengus.

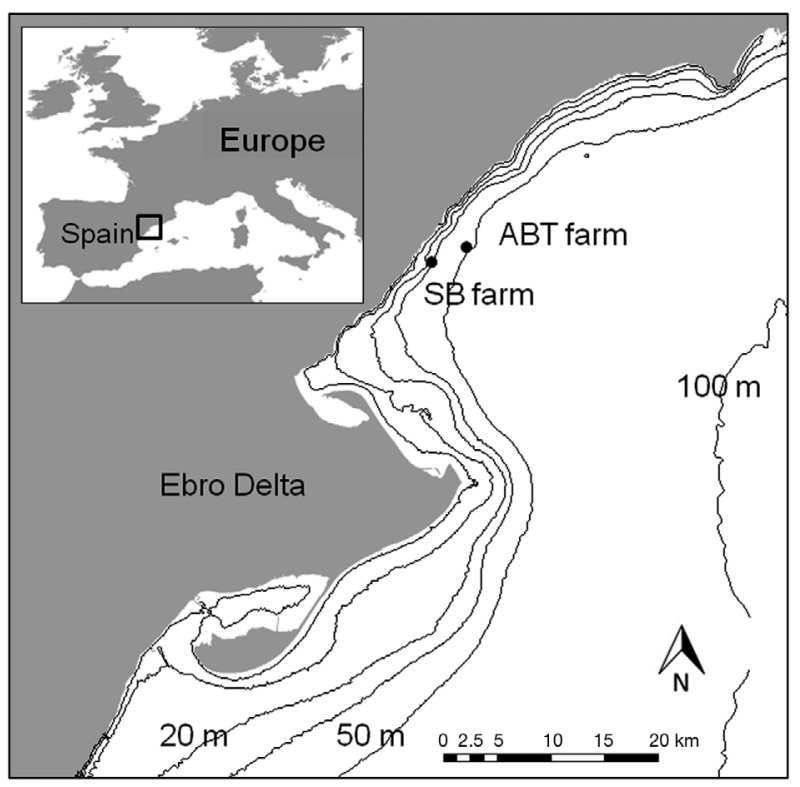

Fig. 1. Study stations adjacent to the Ebro River Delta off the north-eastern coast of Spain. SB: gilthead seabream, ABT: Atlantic bluefin tuna

\section{Water temperature and visibility}

Temperature and underwater visibility displayed high variability during the study period. Water temperature at the 2 farms ranged from a minimum of $12.3^{\circ} \mathrm{C}$ in winter to a maximum of $25.5^{\circ} \mathrm{C}$ in summer. Underwater visibility varied greatly from one day to another, and values were often low, which was expected due to the influence of the Ebro River runoff (Cruzado et al. 2002, Gordoa et al. 2008). The minimum and maximum visibility over the year ranged from 5 to $20 \mathrm{~m}$, with lowest visibilities near the bottom during cold months and highest visibilities at the surface and midwater in summer and spring. Sampling was only conducted on days with at least $5 \mathrm{~m}$ of visibility.

\section{Sampling design}

Wild fish at both fish farms were counted by means of an underwater visual census (UVC). The spatial horizontal design at each farm comprised 3 fixed sampling stations located along a distance gradient from the farm within each farming concession area. The 3 sampling stations were chosen according to the different spatial dimensions of the cages (Fig. 2). Stations were: (1) cage: right next to one of the cages (distance $0 \mathrm{~m}$ ), (2) border: off the edge of the cages (distance: SB farm $30 \mathrm{~m}, \mathrm{ABT}$ farm $100 \mathrm{~m}$ ) and (3)

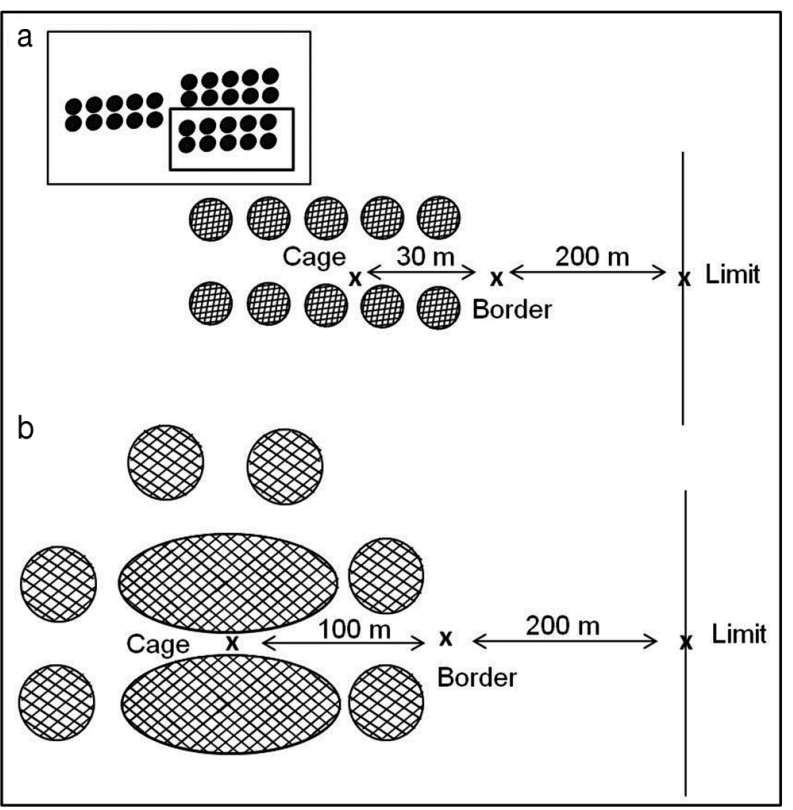

Fig. 2. Layout of the (a) gilthead seabream farm and (b) the Atlantic bluefin tuna (ABT) farm with corresponding sampling stations. Xs indicate the positions of the 3 types of sampling stations (cage, border, limit) 
limit: at the boundary of the leasehold area (distance: $200 \mathrm{~m}$ ). The 3 stations at each farm had the same ecological features: depth, bottom type and distance to the shore. Visual surveys at each station were performed in 3 distinct depth strata: surface $(0-3 \mathrm{~m})$, midwater (8-12 m) and deep/bottom (18-20 m). Bottom depths varied greatly between the 2 farms, hence the deep depth stratum was representative of the bottom at the SB farm but not at the ABT farm. Due to logistical constraints associated with no-decompression diving limits, we chose $20 \mathrm{~m}$, i.e. the bottom depth at the SB farm, as the depth limit for the UVC.

Sampling was carried out from summer 2010 to spring 2011 on 3 randomly selected days per season. At each station, we performed 1 count $\mathrm{d}^{-1}$ depth $^{-1}$, resulting in a total of 108 fish counts at each farm. All surveys were performed during morning hours (8:30 to 12:00 h). The UVC counts were carried out using a method developed by Dempster et al. (2005) which is robust for comparisons of counts at different depth levels and at different visibilities. The method depends on stationary timed counts during which the diver rotates through $360^{\circ}$. To standardize the counts, fish are only counted from $1 \mathrm{~m}$ above to $1 \mathrm{~m}$ below eye level out to a radius of $5 \mathrm{~m}$. Bottom counts at the SB farm were conducted kneeling on the seafloor and spanned the zone from the substrate to $2 \mathrm{~m}$ above. Counts lasted $7 \mathrm{~min}$ at each depth. All UVCs were performed by 2 divers. While the first diver concentrated on estimating the abundance of the dominant species, the second diver looked for more cryptic species. During the $7 \mathrm{~min}$, the maximum number of individual fish of each species observed at any one time was recorded. This made it more unlikely to count the same fish twice. For schools of up to 20 fish, individual fish were counted; for larger shoals, estimates were obtained by subdividing the shoals into imaginary subgroups of equal size, counting the individuals in one of the subgroups and multiplying that count by the number of subgroups. The total length of individuals was recorded, and the biomass was calculated based on published length-weight relationships for each species (Morey et al. 2003, www.fishbase.org). Mugilidae species could not be identified visually to species level and were therefore recorded at the family level. Similarly, Trachurus mediterraneus and T. trachurus were recorded as Trachurus spp.

\section{Statistical analysis}

The assumptions of normality and homogeneity of variance can often be difficult to fulfil with biological data. A good alternative is the analysis of variance based on permutations (PERMANOVA), as it allows multivariate data to be analysed in the context of complex experimental designs and provides a robust approach to deal with skewed data and many zero counts (Anderson 2001). Therefore, all univariate and multivariate statistical analyses were carried out using the PRIMER V6.1.13 computer program (Clarke \& Gorley 2006) with the PERMANOVA+ V1.0.3 add-on package (Anderson et al. 2008).

\section{Univariate analysis}

A univariate PERMANOVA with 3 factors (station, depth, season, all fixed) was performed to test differences in total fish abundance and biomass for each site. The similarity matrix was computed using the Euclidean distance on square root-transformed data, and post hoc pairwise comparisons were used to investigate significant results. In addition, the number of species per station, depth and season was estimated. For direct comparison between the SB and ABT farms, the deep stratum at the SB farm, which represents the bottom community unreachable at the ABT farm, was excluded.

\section{Multivariate analysis}

Permutational multivariate analysis of variance was used to test the differences in wild fish aggregations at the different stations, depth strata and seasons (PERMANOVA, Anderson 2001, Anderson et al. 2008). Prior to analysis, the data were fourth-root transformed in order to downweight the influence of more abundant species, whilst preserving information on relative abundance (Clarke \& Green 1988). Since the BrayCurtis similarity measure is undefined for 2 empty samples, we used the zero-adjusted Bray-Curtis for which a 'dummy species' is added to the original abundance matrix in order to generate meaningful non-metric multidimensional scaling (nMDS) displays (Clarke et al. 2006). nMDS ordinations averaged by season were produced to depict the multivariate patterns of fish aggregations. Statistical significance was tested using 9999 permutations of residuals under a reduced model (Freedman \& Lane 1983) and Type III (partial) sums of squares (SS; Anderson et al. 2008). Significant terms were further examined by applying appropriate post hoc pairwise comparisons. We applied the similarity percentage analysis (SIMPER) routine to examine species contributions to within-group similarity for the most important factor at each farm. 


\section{RESULTS}

\section{Composition of wild fish species}

In total, 14475 individual fish were counted at the SB farm and 5627 at the ABT farm, belonging to 47 species and 23 families (Appendix 1). The vast majority of the species were Osteichthyes, only 4 being Chondrichthyes, including 3 species of rays and 1 blue shark Prionace glauca. In all, 39 species (17 families) were recorded at the SB farm and peripheral stations, the most common families being Sparidae (8 species) and Labridae ( 7 species). At the ABT farm and peripheral stations, 17 species belonging to 9 different families were observed, the most common being Sparidae (4 species) followed by Clupeidae ( 3 species) and Carangidae ( 3 species). The censuses included 2 unusual sightings in the Mediterranean, the barrelfish/driftfish Hyperoglyphe perciformis and the blue shark. Forty of the observed species are targeted by local fishermen. The number of species was higher at the cage than at the border and limit stations at both farms (Appendix 1).

\section{SB farm}

Fish were significantly more abundant at the cage compared to the border and the limit stations (mean \pm SE abundance; cage: $240 \pm 30$, border: $73 \pm 20$, limit: $97 \pm 28$; Table 2, Fig. 3a). Similarly, biomass values were substantially higher at the cage compared to the border and the limit (mean \pm SE biomass in $\mathrm{kg}$; cage: $73.4 \pm 16.6$, border: $2.7 \pm 1.2$, limit: $1.3 \pm 0.4$; Table 2 , Fig. 3b). However, the fish distribution was not homogeneous across depths. Significant differences in abundance and biomass at the cage compared to the border and the limit were only observed in the midwater and surface strata. At the bottom, abundance and biomass did not vary between the cage and the border but were significantly higher than at the limit (Fig. 3a,b). Overall, fish were more abundant at the bottom compared to the midwater $(3$ times; $\mathrm{p}<0.001)$ and surface strata (2.4 times; $\mathrm{p}<$ 0.001; Table 2), although total fish biomass did not differ among depths (Fig. 3a,b). Fish abundance and biomass at the cage did not vary by season except in autumn, when small species were most abundant, resulting in significantly lower biomass values at that time of year. The higher abundance and biomass observed at the cage was constant all year round, except in autumn, when fish abundance at the cage was not significantly higher than at the limit (Fig. 3c,d, Table 2, triple interaction). Fish abundance at the limit revealed a different seasonal pattern compared to the other stations, attaining the highest values in summer and autumn and the lowest values in winter and spring (Fig. 3c).

At the cage, the species composition differed significantly from those at the border and the limit (Table 2). However, variability in the fish community was heavily depth-dependent, with a clear separation between the bottom and the water column (midwater and surface strata) all year round (nMDS ordination; Fig. 4). Midwater and surface aggregations differed from each other only in summer (Table 2). SIMPER analysis showed that assemblages at the bottom were stable over time at all stations and were largely (>50\%) represented by 3 species (Chromis chromis, Coris julis and Serranus cabrilla; Table 3). In contrast, cage-aggregations in the water column differed significantly from those at the border and the limit, mirroring the spatial and seasonal aggregation patterns found for abundance and biomass (Table 2).

Table 2. Gilthead seabream (SB) farm: summary of results of permutational univariate and multivariate analysis of variance comparing abundance, biomass and species community for the factors station (ST), depth (DE) and season (SE) and post hoc tests for significant factors and interactions. C: cage, B: border, L: limit; D: deep water, M: midwater, S: surface; SU: summer, AU: autumn, WI: winter, SP: spring. Significant at ${ }^{*} p<0.05,{ }^{* *} p<0.01,{ }^{* * *} p<0.001$

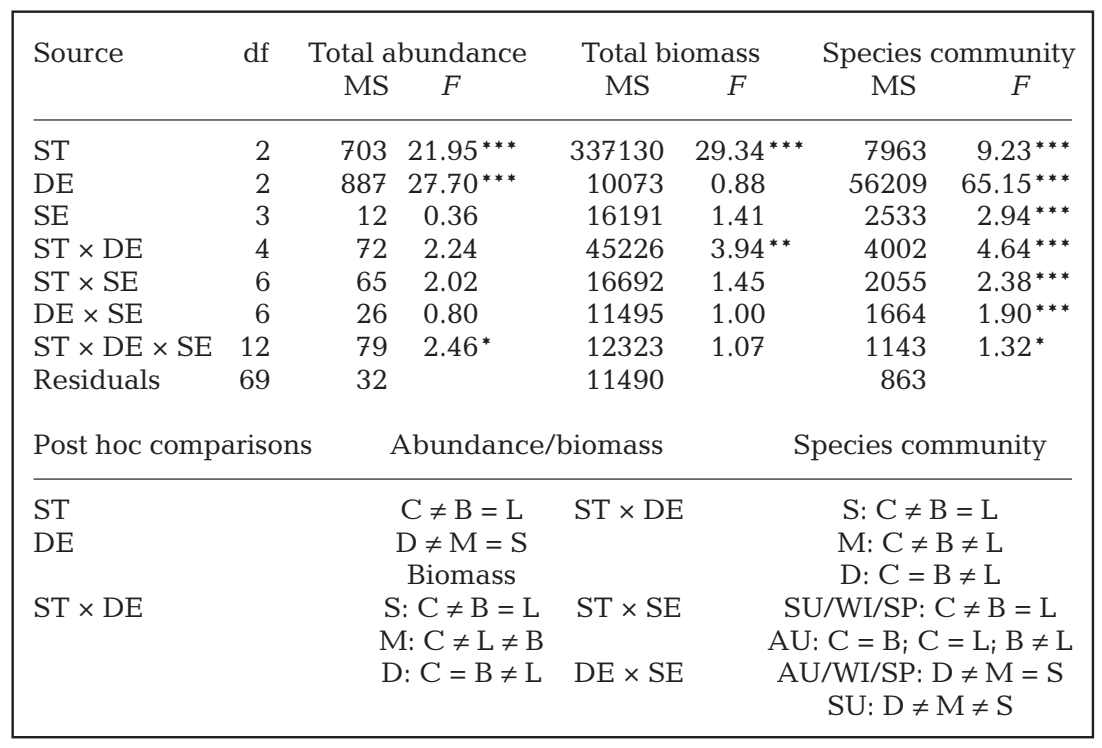



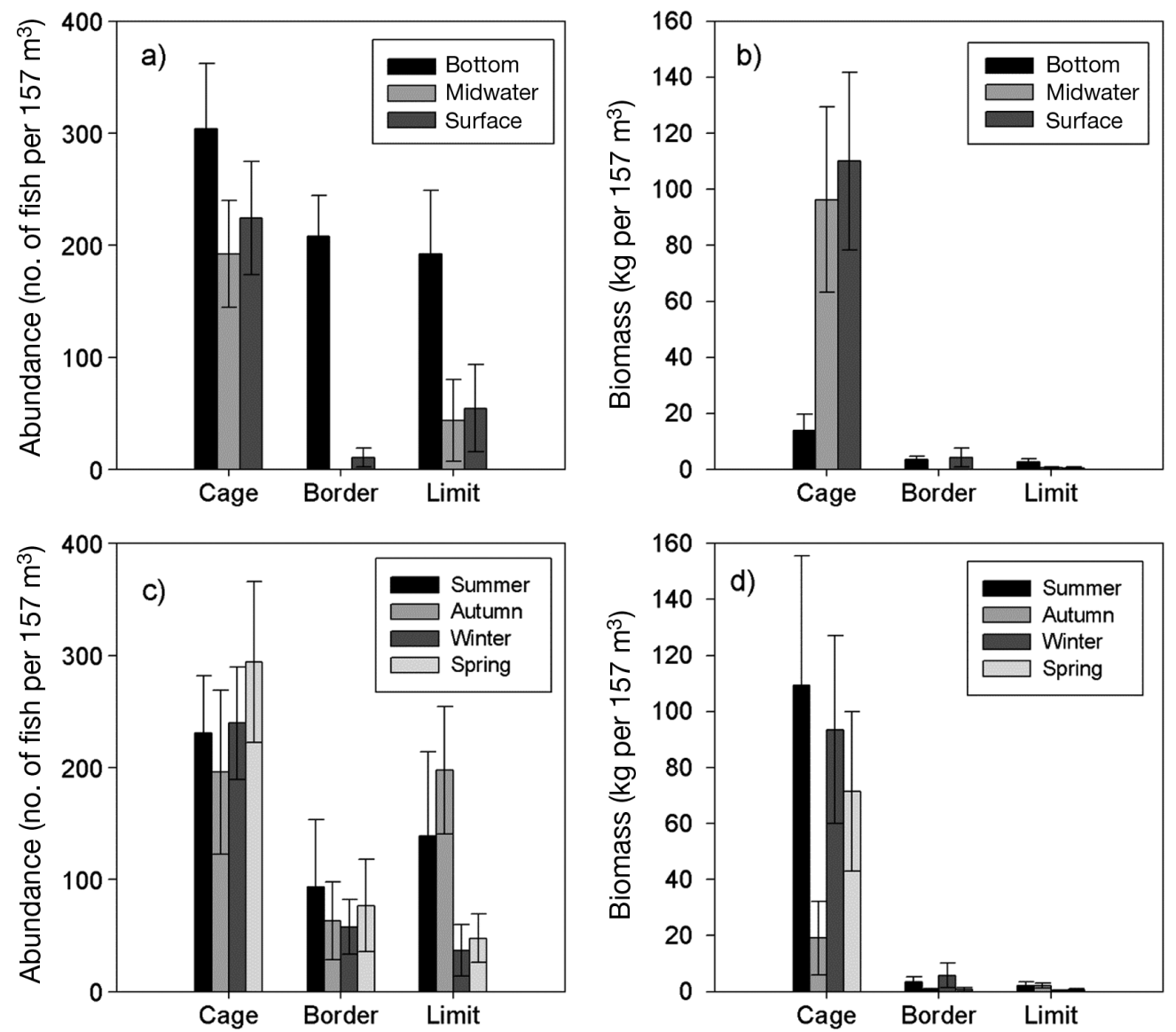

Fig. 3. Total abundance and biomass (kg) of wild fish at the gilthead seabream (SB) farm (a,b) by sampling station and depth and $(\mathrm{c}, \mathrm{d})$ by sampling station and season. Bars are mean \pm SE of 12 underwater visual counts in a volume of $157 \mathrm{~m}^{3}$

This aggregation pattern was stable over time, except in autumn, when fish assemblages at the cage did not differ from those at the border and the limit (Table 2). Cage-aggregations in the water column were dominated by 6 species which accounted for $94 \%$ of total abundance (Fig. 5). Abundance values for these species varied by season, each season being characterised by a different combination of species (summer: Oblada melanura, Mugilidae, Trachinotus ovatus, $C$. chromis and Sarpa salpa; autumn: Boops boops; winter: O. melanura, B. boops; spring: C. chromis, O. melanura, Mugilidae; Fig. 5).

\section{ABT farm}

The majority of fish were observed at the cage, where abundance values were higher than at the border and the limit (mean $\pm \mathrm{SE}$ abundance; cage: $113 \pm 28$, border: $12 \pm 4$, limit: $31 \pm 10$; Table 4 ) . Likewise, fish biomass was substantially higher at

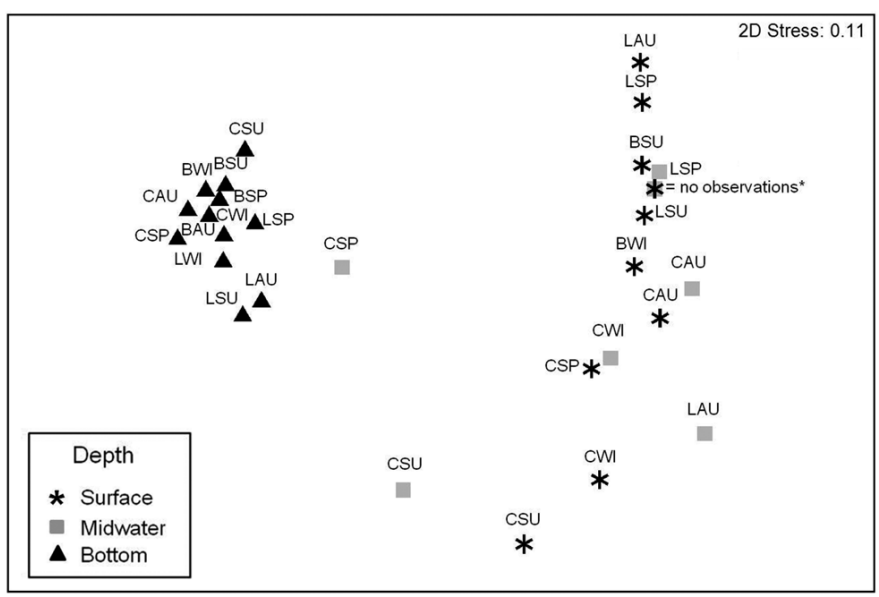

Fig. 4. Non-metric multidimensional scaling ordination plot of wild fish assemblages at the gilthead seabream (SB) farm based on a Bray-Curtis similarity matrix of fourth-root transformed abundance data, averaged per season $(\mathrm{C}=$ cage, $\mathrm{B}=$ border, $\mathrm{L}=$ limit; $\mathrm{SU}=$ summer, $\mathrm{AU}=$ autumn, $\mathrm{WI}=$ winter, $\mathrm{SP}=$ spring). Samples without fish observations ('no observations') were placed together; surface: BSP, LWI, BSU; midwater: BSU, LSU, BSP, BAU, BWI, LWI. Stress $=0.11$ 
Table 3. Gilthead seabream (SB) farm. Results of the similarity percentage analysis showing the species contribution to within-group similarity (\%) by sampling station and depth stratum. Full species names are listed in Appendix 1

\begin{tabular}{|c|c|c|c|c|c|c|}
\hline & Cage & $\%$ & Border & $\%$ & Limit & $\%$ \\
\hline Surface & $\begin{array}{l}\text { O. melanura } \\
\text { B. boops }\end{array}$ & $\begin{array}{l}83.0 \\
10.1\end{array}$ & All similarities are zero & & S. pilchardus & 100.0 \\
\hline Midwater & $\begin{array}{l}\text { C. chromis } \\
\text { Mugilidae } \\
\text { O. melanura }\end{array}$ & $\begin{array}{l}39.3 \\
27.5 \\
23.8\end{array}$ & No species observed & & B. boops & 100.0 \\
\hline Bottom & $\begin{array}{l}\text { C. chromis } \\
\text { S. cabrilla } \\
\text { C. julis } \\
\text { G. xanthocephalus } \\
\text { P. pilicornis } \\
\text { S. scriba } \\
\text { P. rouxi } \\
\text { D. vulgaris }\end{array}$ & $\begin{array}{r}32.0 \\
17.1 \\
16.9 \\
7.4 \\
7.1 \\
5.0 \\
4.1 \\
4.1\end{array}$ & $\begin{array}{l}\text { C. chromis } \\
\text { C. julis } \\
\text { S. cabrilla } \\
\text { S. scriba } \\
\text { D. vulgaris } \\
\text { G. xanthocephalus }\end{array}$ & $\begin{array}{r}33.1 \\
19.4 \\
14.0 \\
12.8 \\
8.0 \\
4.3\end{array}$ & $\begin{array}{l}\text { C. chromis } \\
\text { C. julis } \\
\text { D. vulgaris } \\
\text { S. cabrilla } \\
\text { O. melanura }\end{array}$ & $\begin{array}{r}34.0 \\
23.7 \\
16.1 \\
12.9 \\
3.9\end{array}$ \\
\hline
\end{tabular}

the cage compared to the border and the limit (mean \pm SE biomass in $\mathrm{kg}$; cage: $424.8 \pm 158.4$, border: $4.2 \pm$ 2.3, limit: $5.1 \pm 4.3, \mathrm{p}<0.001$; Table 4, Fig. 6a,b). Abundance and biomass at the cage varied significantly with season (Table 4), with higher values in summer and spring compared to autumn and winter (Fig. 6c,d). Indeed, fish biomass was strongly affected by seasonality, and as a consequence higher biomass values at the cage compared to the border and the limit were only detectable in summer and spring (Fig. 6d) and were restricted to the deep and midwater strata (significant interactions, Table 4, Fig. 6b). Overall, the highest fish biomass was recorded for the deep and midwater strata. However, these high values only occurred in summer, due to the presence of wild Thunnus thynnus which contributed $94.3 \%$ to the total fish biomass recorded in this season. During the rest of the year, no differences were recorded among depths (Table 4).

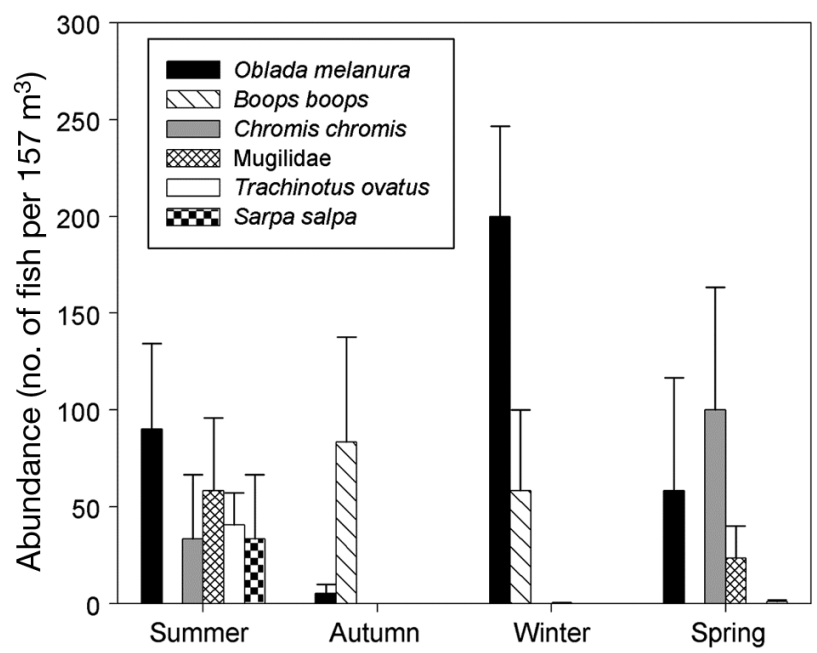

Fig. 5. Total abundance (mean $\pm \mathrm{SE}$ ) of the 6 most abundant species at the gilthead seabream (SB) farm in the midwater and surface strata at the cage by season
Wild fish communities at the cage differed significantly from those at the border and the limit in all 3 depth strata (Table 4). SIMPER analysis revealed that cage assemblages consisted mainly of 4 species (Thunnus thynnus, Oblada melanura, Sarpa salpa and Sardina pilchardus), which accounted for $91 \%$ of the group similarity. By contrast, fish aggregations at the border and the limit were dominated by Trachurus spp. (59\%), Hyperoglyphe perciformis (22\%) and Seriola dumerili $(10 \%)$. The separation of the cage aggregations from the border and limit aggregations was confirmed by the nMDS ordination, but there was no clear interpretation for samples by depth and season (Fig. 7). Differences in fish aggregation patterns were only observed during summer and spring, while in autumn and winter, fish assemblages were stationindependent (Table 4). Assemblages at the cage in summer and spring were clearly dominated by $T$. thynnus. Conversely, T. thynnus was never recorded at either the border or limit stations (Table 5). In autumn and winter, fish assemblages at the 3 stations were mainly composed of different species (Table 5). Assemblages at different depths did not differ by season except in summer, when there was a different predominant species at each depth (surface: $S$. dumerili, midwater: T. thynnus, deep: Sarda sarda). At the cage, each season exhibited a different species prevalence (summer: O. melanura, Scomber japonicus, T. thynnus; autumn: O. melanura; winter: O. melanura, S. salpa; spring: O. melanura, S. pilchardus, S. japonicus, S. salpa, Sardinella aurita, T. thynnus), which together accounted for $91 \%$ of total fish abundance (Fig. 8).

\section{Inter-farm differences}

The greater species diversity and fish abundance recorded at the SB farm was ascribable to the bottom 
Table 4. Atlantic bluefin tuna (ABT) farm. Summary of results of permutational univariate and multivariate analysis of variance comparing abundance, biomass and species community for the factors station (ST), depth (DE) and season (SE) and post hoc tests for significant factors and interactions. C: cage, B: border, L: limit; D: deep water, M: midwater, S: surface; SU: summer, AU: autumn, WI: winter, SP: spring. Significant at ${ }^{*} p<0.05,{ }^{* *} p<0.01,{ }^{* * *} p<0.001$, ns $=$ non-significant

\begin{tabular}{|c|c|c|c|c|c|c|c|}
\hline \multirow[t]{2}{*}{ Source } & \multirow[t]{2}{*}{$\mathrm{df}$} & \multicolumn{2}{|c|}{ Total abundance } & \multicolumn{2}{|c|}{ Total biomass } & \multicolumn{2}{|c|}{ Species community } \\
\hline & & $\mathrm{Ms}$ & $F$ & MS & $F$ & MS & $F$ \\
\hline ST & 2 & 293.9 & $910.20^{* * *}$ & 1195600 & $30.83^{* * *}$ & 6757 & $7.08^{* * *}$ \\
\hline $\mathrm{DE}$ & 2 & 47.4 & $5 \quad 1.65$ & 434790 & $11.21^{* * *}$ & 5507 & $5.77^{* * *}$ \\
\hline $\mathrm{SE}$ & 3 & 97.1 & $3.37^{*}$ & 602830 & $15.54^{* * *}$ & 5411 & $5.67^{* * *}$ \\
\hline $\mathrm{ST} \times \mathrm{DE}$ & 4 & 71.0 & 2.47 & 301250 & $7.77^{* * *}$ & 3484 & $3.65^{* * *}$ \\
\hline $\mathrm{ST} \times \mathrm{SE}$ & 6 & 31.6 & 1.10 & 379900 & $9.79^{* * *}$ & 1934 & $2.03^{* *}$ \\
\hline $\mathrm{DE} \times \mathrm{SE}$ & 6 & 12.1 & 0.42 & 169150 & $4.36^{* * *}$ & 2217 & $2.32^{* * *}$ \\
\hline $\mathrm{ST} \times \mathrm{DE} \times \mathrm{SE}$ & 12 & 14.8 & 0.51 & 116090 & $2.99^{* *}$ & 1241 & 1.30 \\
\hline Residuals & 72 & 28.8 & & 38785 & & 954 & \\
\hline \multicolumn{4}{|c|}{ Post hoc comparisons } & \multicolumn{2}{|c|}{ Biomass } & \multicolumn{2}{|c|}{ Species community } \\
\hline \multirow{6}{*}{$\begin{array}{lr}\text { ST } & \\
\text { DE } & n \\
\text { SE } & \text { SU }\end{array}$} & \multirow{4}{*}{\multicolumn{2}{|c|}{$\begin{array}{l}\text { / Biomass } \\
=\mathrm{L} \\
\mathrm{M}=\mathrm{S} \\
\mathrm{WI}=\mathrm{AU}\end{array}$}} & \multirow{2}{*}{$\mathrm{ST} \times \mathrm{DE}$} & \multirow{3}{*}{\multicolumn{2}{|c|}{$\begin{array}{l}S: C=B=L \\
M: C \neq B=L \\
D: C \neq B=L\end{array}$}} & \multicolumn{2}{|c|}{$S: C \neq B=L$} \\
\hline & & & & & & \multirow{2}{*}{\multicolumn{2}{|c|}{$\begin{array}{l}M: C \neq B=L \\
D: C \neq B \neq L\end{array}$}} \\
\hline & & & \multirow[b]{2}{*}{$\mathrm{ST} \times \mathrm{SE}$} & & & & \\
\hline & & & & \multicolumn{2}{|c|}{$\begin{array}{l}\text { SU/SP: } C \neq B=L \\
\text { AU/WI. } C=B=I\end{array}$} & \multirow{2}{*}{\multicolumn{2}{|c|}{$\begin{array}{c}\text { SU/SP: } C \neq B=L \\
\text { AU/WI: } C=B=L \\
\text { SU: } D \neq M \neq S\end{array}$}} \\
\hline & & & \multirow{2}{*}{$\mathrm{DE} \times \mathrm{SE}$} & \multicolumn{2}{|c|}{$\begin{array}{c}\text { AU/WI: } C=B=L \\
\text { SU: } D=M \neq S\end{array}$} & & \\
\hline & & & & \multicolumn{4}{|c|}{ AU/WI/SP: $\mathrm{D}=\mathrm{M}=\mathrm{S}$ AU/WI/SP: $\mathrm{D}=\mathrm{M}=\mathrm{S}$} \\
\hline
\end{tabular}

community (26 species, see Appendix 1), which was excluded from the comparative analysis performed here (see 'Materials and methods'). The results of previous statistical analyses carried out in the present study showed that attraction at both farms was restricted to the cage station, though with significant differences by season. Taking into account only the cage sampling station at both farms, we recorded a total of 5001 individual fish (10 species) at the SB farm and 4053 fish (16 species) at the ABT farm. The total sampled fish biomass at the cage during the study period was 6 times higher at the ABT farm (15.3 $\mathrm{t} \mathrm{yr}^{-1}$ ) compared to the SB farm $\left(2.5 \mathrm{t} \mathrm{yr}^{-1}\right)$. Species diversity at both farms was highest in spring and summer. The seasonal variations in abundance at both farms
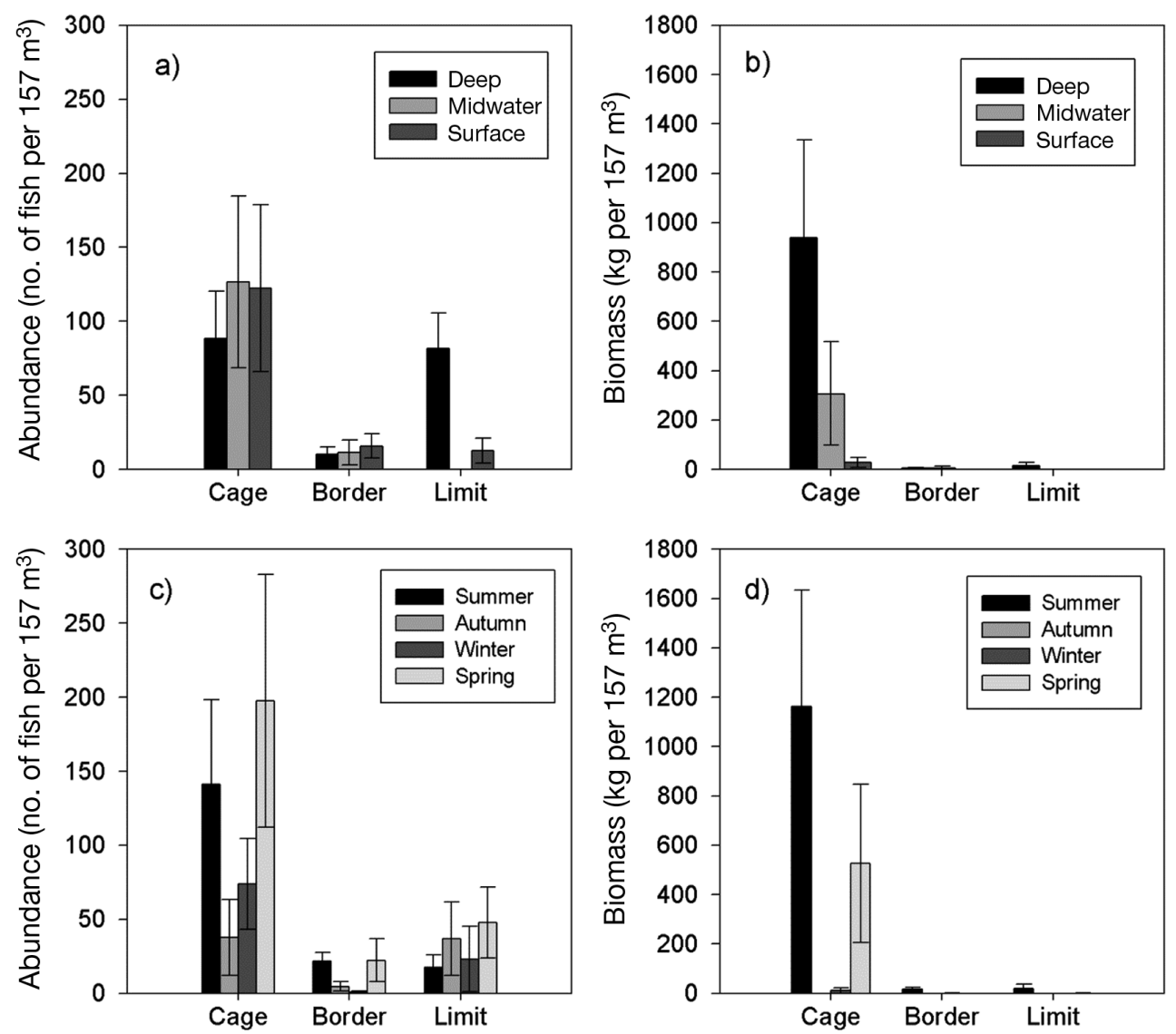

Fig. 6. Total abundance and biomass (kg) of wild fish at the Atlantic bluefin tuna (ABT) farm (a,b) by sampling station and depth and $(\mathrm{c}, \mathrm{d})$ by sampling station and season. Bars are mean $\pm \mathrm{SE}$ of 12 underwater visual counts in a volume of $157 \mathrm{~m}^{3}$ 


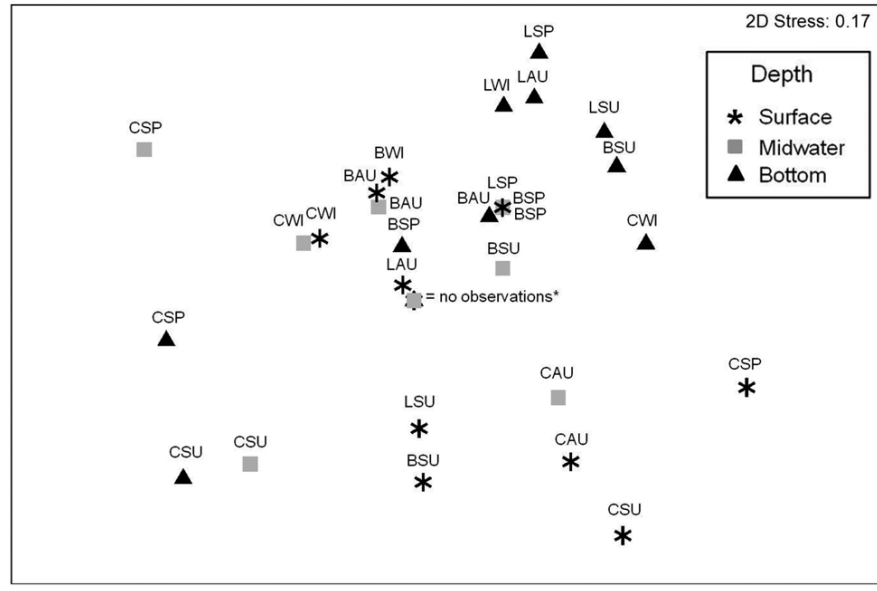

Fig. 7. Non-metric multidimensional scaling ordination plot of wild fish assemblages at the Atlantic bluefin tuna (ABT) farm based on a Bray-Curtis similarity matrix of fourth-root transformed abundance data, averaged per season $(\mathrm{C}=$ cage, $\mathrm{B}=$ border, $\mathrm{L}=$ limit; $\mathrm{SU}=$ summer, $\mathrm{AU}=$ autumn, $\mathrm{WI}=$ winter, $\mathrm{Sp}=$ spring). Samples without fish observations ('no observations') were placed together; surface: BSP, LWI, LSP; midwater: BWI,

BSP, LSU, LAU, LWI, LSP; deep: CAU, BWI. Stress $=0.17$

notwithstanding, differences between the farms were recorded all year long except in spring (Fig. 9).

\section{DISCUSSION}

Our study revealed a strong attraction effect for wild fish at both investigated fish farm facilities. Cage aggregations differed from those at the border and limit stations in abundance, biomass and fish community, revealing an abrupt decline in aggregated fish at a short distance from the cage rather than a gradient. However, the spatial and temporal extent of the cage attraction effect was different at each farm type. Different species exhibited speciesspecific spatial and seasonal aggregation patterns, depending on their ecology.
The SB farm attracted large aggregations of wild fish throughout the year, and no seasonal variability in abundance was recorded, indicating that this aquaculture facility provides a permanent habitat for local fish populations. There were 2 depth-specific fish assemblages: a bottom community characterised by high diversity (35 species) and a water-column community composed mainly of 6 species. The total number of species recorded was more than twice the maximum previously reported at SB farms in the Mediterranean (Dempster et al. 2002). We attribute this difference to the absence of any analysis of the bottom community in most previous studies, with the exception of Dempster et al. (2005), in which the sandy bottom type may have been responsible for the lower diversity (14 species), fish abundance and biomass being higher in the water column than on the bottom. Contrary to the abundance pattern, our biomass results corroborated the findings of Dempster et al. (2005) because of species size differences at the different depths.

SB community composition on the bottom was represented by the typical Mediterranean reef fish species (e.g. Dufour et al. 1995, García-Charton \& Pérez-Ruzafa 2001, Gordoa 2009) at all 3 sampling stations and was very stable over time. Differences in abundance were observed only at the limit of the leasehold area, probably caused by lower abundance of just a few benthic species, such as blennids and gobiids. This difference suggests that bottom fish species are also attracted to the high food availability around the cages. Moreover, this shows that the SB farm did not exert a negative effect on the fish community on the rocky bottom underneath the farm. At farms that aggregate both pelagic and demersal species, unconsumed food and faeces from farmed fish will be consumed in the water column and at the bottom. It thus follows that the mitigating influence of wild fish on farm effluent dispersal should be consid-

Table 5. Atlantic bluefin tuna (ABT) farm. Results of the similarity percentage analysis showing the species contribution to within-group similarity (\%) by season at the 3 sampling stations. Full species names are listed in Appendix 1

\begin{tabular}{|c|c|c|c|c|c|c|c|c|}
\hline & Summer & $\%$ & Autumn & $\%$ & Winter & $\%$ & Spring & $\%$ \\
\hline \multirow[t]{2}{*}{ Cage } & T. thynnus & 81.1 & \multirow[t]{2}{*}{ O. melanura } & \multirow[t]{2}{*}{100.0} & \multirow[t]{2}{*}{ S. salpa } & \multirow[t]{2}{*}{100.0} & T. thynnus & 58.5 \\
\hline & S. dumerili & 9.6 & & & & & S. pilchardus & 35.0 \\
\hline \multirow[t]{3}{*}{ Border } & S. dumerili & 52.6 & B. capriscus & 58.6 & \multirow[t]{3}{*}{ H. perciformis } & \multirow[t]{3}{*}{100.0} & \multirow[t]{3}{*}{ Trachurus spp. } & \multirow[t]{3}{*}{100.0} \\
\hline & S. sarda & 30.8 & H. perciformis & 41.4 & & & & \\
\hline & Trachurus spp. & 16.7 & & & & & & \\
\hline \multirow[t]{3}{*}{ Limit } & S. sarda & 41.5 & \multirow[t]{3}{*}{ Trachurus spp. } & \multirow[t]{3}{*}{100.0} & \multirow[t]{3}{*}{ H. perciformis } & \multirow[t]{3}{*}{100.0} & \multirow[t]{3}{*}{ Trachurus spp. } & \multirow[t]{3}{*}{94.9} \\
\hline & S. dumerili & 35.9 & & & & & & \\
\hline & Trachurus spp. & 22.6 & & & & & & \\
\hline
\end{tabular}




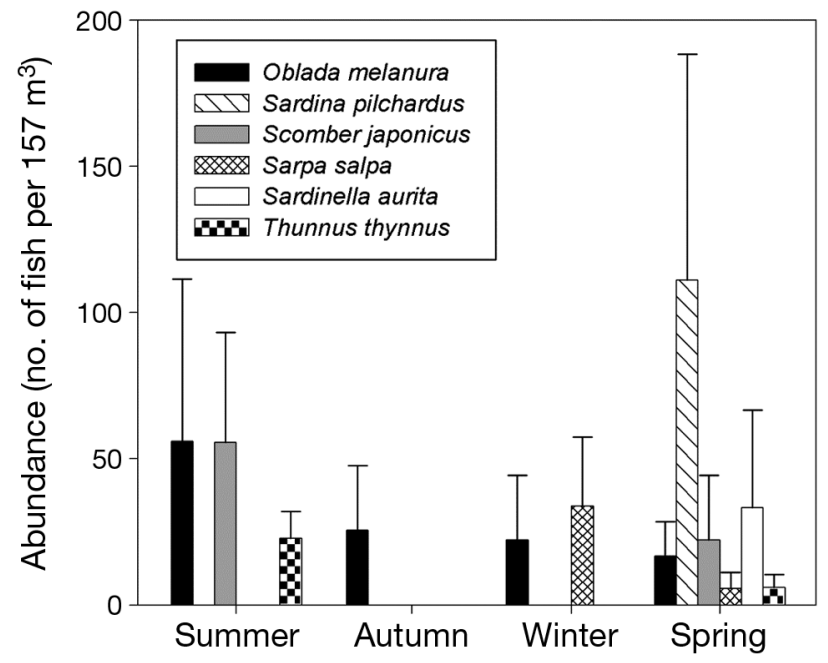

Fig. 8. Total abundance (mean $\pm \mathrm{SE}$ ) of the 6 most abundant species at the Atlantic bluefin tuna (ABT) farm at the cage by season

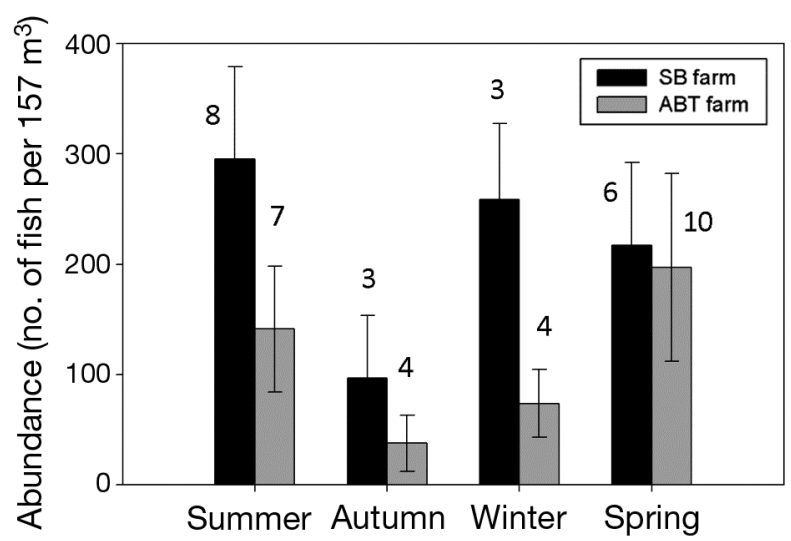

Fig. 9. Total abundance (means \pm SE) and number of fish species (on top of bars) at the cage by season at the gilthead seabream (SB) and Atlantic bluefin tuna (ABT) farms. Values for the SB farm include counts from the midwater and surface strata only (see 'Materials and methods')

ered, and it has been suggested that farms may be better sited over artificial reefs (Angel et al. 2002) that could increase consumption of waste particles. Similarly, mixed rocky-sandy bottoms, which sustain a more numerous and diverse fish community than sandy bottoms, may have the potential to increase waste particle consumption. Still, the impact on other rocky bottom organisms needs to be taken into account.

The fish community in the water column at the cage was dominated by a relatively small number of species (Oblada melanura, Boops boops, Chromis chromis, Mugilidae, Trachinotus ovatus and Sarpa salpa) which, except for C. chromis, have been reported to dominate fish aggregations in previous SB farm studies (e.g. Dempster et al. 2002, Fernandez-Jover et al. 2008). Due to the rocky-sandy bottom, we observed high abundances of C. chromis year round, which indicates that bottom type also exerts an influence on the water column community. Larger individuals of $C$. chromis frequently moved from the bottom to a depth of $10 \mathrm{~m}$ and fed actively on uneaten food pellets. The seasonal aggregation patterns of the most abundant species $O$. melanura (all year long) and B. boops (higher abundance in autumn and winter) were consistent with the results of previous studies (Valle et al. 2007, FernandezJover et al. 2008). Some species such as Diplodus sargus and Pomatomus saltatrix were observed when we entered the water before starting the survey but were seldom recorded during counting. Thus, we presume that these species avoid divers and are underestimated with the scuba diving methodology. These limitations of underwater visual counts have been described in previous studies (e.g. Thresher \& Gunn 1986).

The ABT farm attracted large aggregations of wild fish, although this effect exhibited strong seasonal variability. Our censuses recorded 17 species compared to the 20 species recorded at 2 Croatian ABT farms (Šegvić Bubić et al. 2011). Substantial differences in the species composition between the Croatian farms and the Spanish farm would appear to be caused by the presence of littoral reef-associated species at the Croatian farms as a result of ecological differences between the farm locations. In both studies, the farms were situated over similar bottoms and depths. The most relevant difference between the locations was the distance from shore, i.e. $200 \mathrm{~m}$ for the Croatian farms and $4500 \mathrm{~m}$ for the Spanish farm, with the associated difference in slope steepness and the proximity of the continental shelf. These bathymetrical features at the Croatian farms were conducive to the presence of both littoral reef-associated and oceanodromous species. At the Spanish ABT farm, the seasonality of pelagic species such as Sardina pilchardus, Scomber japonicus, Sardinella aurita, Sarda sarda, Seriola dumerili and Thunnus thynnus strongly influenced the seasonality of the cage effect, limiting it to summer and spring. Although the Croatian farms were also subject to the seasonality effects of oceanodromous species, the permanent high abundances of Boops boops and Belone belone resulted in a year-long attraction effect at the Croatian farms (Šegvić Bubić et al. 2011). The seasonal variability of the cage effect in 
the present study was mainly attributable to the seasonal occurrence of $T$. thynnus. The presence of this species during summer-spring and its absence in autumn-winter can be explained by its spawning season and migratory pattern (Rooker et al. 2007). Nevertheless, the presence of $T$. thynnus around the ABT farm continued at least until December in 2011 (pers. com. of the Balfegó Group, L'Ametlla de Mar, Spain, outside the study period). The attraction of wild T. thynnus to ABT farms is beginning to elicit a new scientific topic, namely, whether farms could alter $T$. thynnus migration patterns. At the ABT farm investigated in the present study, no escapement ever occurred, and the closest ABT farm facilities are at a distance of $\sim 550 \mathrm{~km}$ (Cartagena, Spain), hence; the possibility that the observed individuals of $T$. thynnus were feral animals that escaped from a farm was considered very small. The present study also yielded some additional information from the ABT farm which has not been expressly analysed but which we believe is worth mentioning. Specifically, only small individuals of the species Oblada melanura, Mugilidae, Sarpa salpa, Seriola dumerili, Trachinotus ovatus and Sardina pilchardus were recorded; in total, $65 \%$ of cage aggregated fish were $<11 \mathrm{~cm}$. Individuals of that size are not likely to feed on whole baitfish and may feed on very small particles of baitfish and/or living organisms that cover the cage ropes. It is therefore reasonable to assume that these small individuals are attracted not only to the available food but also to the farm structures in search of shelter, as has been suggested by other authors (Fernandez-Jover et al. 2009, Šegvić Bubić et al. 2011). In addition, at the beginning of July 2011 during monitoring of $T$. thynnus spawning in captivity that our group has been carrying out since 2008 (Gordoa et al. 2009), we collected 2 types of eggs inside the ABT cage that could be genetically determined as $T$. thynnus and Trachurus mediterraneus. Thus, ABT farms may act as new spawning grounds with unknown viability for larvae, but they at least have the potential to provide eggs as food for aggregated species.

Further, we observed the unexpected presence of the barrelfish/driftfish at the ABT farm all year round, except in summer. This species, which typically has an Atlantic distribution, has only been observed once in the Mediterranean (Karrer 1986). In addition, we made the first sighting of a blue shark, circling the farm near the surface in spring.

Our results revealed differences and similarities between the 2 fish farm models considered here. At both farms, the attraction effect was mostly constrained to the cage station. The seasonal occurrence of pelagic species restricted the attraction effect to summer and spring at the ABT farm, whereas the SB farm attracted fish all year long. Nevertheless, the cage attraction effect, compared to border and limit stations, was considerably stronger at the ABT farm. Differences in fish abundance and species composition recorded at the $\mathrm{SB}$ and $\mathrm{ABT}$ farms may be related to the type of food used and/or the type of habitat at each farm. Whole baitfish differ substantially in their nutrient composition, food size and settling velocity from the food pellets used at SB farms (Vassallo et al. 2006). Šegvić Bubić et al. (2011) suggested that the pellets and their fine particulates may attract a more diverse fish community and can be more easily consumed than baitfish. In addition, the ABT farm is located 4 times as far from shore over deeper, muddy bottoms, compared to the shallower mixed rocky-sandy seafloor of the SB farm. The exposed situation of the ABT farm compared to the SB farm attracts more mobile pelagic species, from small plankton feeders (e.g. Sardina pilchardus and Sardinella aurita) to big species such as Thunnus thynnus whose diet is mostly based on small pelagics.

Fishing near fish farms is a common practice that has been reported in Spain (Fernandez-Jover et al. 2008, Arechavala-Lopez et al. 2011), Croatia (Šegvić Bubić et al. 2011), Greece (Machias et al. 2006) and Norway (Maurstad et al. 2007), and even within farms in Turkey (Akyol \& Ertosluk 2010). The farms studied here are located in waters within the jurisdiction of the local government, which has not implemented any fishing restrictions in their vicinity. Nonetheless, the cages are located in the centre of the leasehold farm area, and their distance from the perimeter acts as a protective zone for wild fish. The potential for farms to protect wild fish highly depends on the behaviour of each particular species. The results of the current study show that the majority of aggregated fish concentrated in close proximity to the cage and suggest that they are to some extent protected. The territorial species recorded at the SB farm all year long reap the greatest protection. In contrast, pelagic and semipelagic species that conduct seasonal movements away from the farm (e.g. Thunnus thynnus, Scomber japonicus, Sarda sarda, Sardina pilchardus) are only partly protected by the farm area. In addition, daily movements could substantially increase fish vulnerability. A study by Arechavala-Lopez et al. (2010) recorded rapid and repeated movements of grey mullets Chelon labrosus and Liza aurata to other farms and to nearby fishing areas. To date, no data on the efficiency of fishing near farm boundaries exist. The presence of a species 
of such high commercial value as T. thynnus at such a short distance from the coast could trigger illegal fishing activities from fleets that do not have any quota allocation (Spanish Mediterranean artisanal fleet) or only a very limited allocation with a short fishing period (recreational fleet). During the study, large numbers of recreational fishing vessels were observed gathering at the concession boundary to presumably target this species. Further, the potential of farms to attract rare species, such as the blue shark and the barrelfish/driftfish, requires the implementation of conservation actions.

Our work emphasizes the importance of applying an integrated approach to study wild fish aggregations at farms. The spatial extent of fish attraction is a key item of information for determining the effective size of an appropriate protection zone around farms. Data on the seasonal aggregation pattern provides knowledge of periods when exploited species are especially vulnerable at farms. As demonstrated here, different farm types exhibit distinct fish aggregation patterns which may require different regulatory measures. Without such measures, the proliferation of fish farming facilities along the coast might result in the decline of a number of highly targeted fish species.

Acknowledgements. K.B. was supported by a JAEPre 2010_01276 scholarship from the Spanish National Research Council (CSIC). We thank M.J. Anderson (Massey University, New Zealand) for valuable advice on the statistical analysis and J. Viñas (University of Girona, Spain) for the genetic analysis of fish eggs. We are grateful to the gilthead seabream farm company (Grupo INVERMAR) and the Atlantic bluefin tuna farm Balfegó Grup who granted us access to their installations. Special thanks go to the Vicepresident O. Ribalta and several members of the Responsible Recreational Fishing Association for providing their time and their vessels: C. Marti, C. Marti Jr., C. Gomez, C. Garín, L. Roca, R. Roca, J. Labiano, C. Seto and L. Martínez.

\section{LITERATURE CITED}

Akyol O, Ertosluk O (2010) Fishing near sea-cage farms along the coast of the Turkish Aegean Sea. J Appl Ichthyol 26:11-15

Anderson MJ (2001) A new method for non-parametric multivariate analysis of variance. Austral Ecol 26:32-46

Anderson MJ, Gorley RN, Clarke KR (2008) PERMANOVA+ for PRIMER: guide to software and statistical methods. PRIMER-E, Plymouth

Angel DL, Eden N, Breitstein S, Yurman A, Katz T, Spanier E (2002) In situ biofiltration: a means to limit the dispersal of effluents from marine finfish cage aquaculture. Hydrobiologia 469:1-10

Arechavala-Lopez P, Uglem I, Sanchez-Jerez P, FernandezJover D, Bayle-Sempere J, Nilsen R (2010) Movements of grey mullet Liza aurata and Chelon labrosus associated with coastal fish farms in the western Mediterranean Sea. Aquacult Environ Interact 1:127-136

Arechavala-Lopez P, Sanchez-Jerez P, Bayle-Sempere J, Fernandez-Jover D, Martinez-Rubio L, Lopez-Jimenez JA, Martinez-Lopez FJ (2011) Direct interaction between wild fish aggregations at fish farms and fisheries activity at fishing grounds: a case study with Boops boops. Aquacult Res 42:996-1010

> Bell JD (1983) Effects of depth and marine reserve fishing restrictions on the structure of a rocky reef fish assemblage in the north-western Mediterranean Sea. J Appl Ecol 20:357-369

Boyra A, Sanchez-Jerez P, Tuya F, Espino F, Haroun R (2004) Attraction of wild coastal fishes to an Atlantic subtropical cage fish farms, Gran Canaria, Canary Islands. Environ Biol Fishes 70:393-401

Burbridge PR (1999) The challenge of demonstrating the socio-economic benefits of integrated coastal management. In: Salomons W, Turner RK (eds) Perspectives on integrated coastal zone management. Springer-Verlag, Heidelberg, p 35-53

Carss DN (1990) Concentrations of wild and escaped fishes immediately adjacent to fish farm cages. Aquaculture 90: $29-40$

Clarke KR, Gorley RN (2006) PRIMER v6: user manual/ tutorial. PRIMER-E, Plymouth

Clarke KR, Green RH (1988) Statistical design and analysis for a 'biological effects' study. Mar Ecol Prog Ser 46: 213-226

> Clarke KR, Somerfield PJ, Chapman MG (2006) On resemblance measures for ecological studies, including taxonomic dissimilarities and a zero-adjusted Bray-Curtis coefficient for denuded assemblages. J Exp Mar Biol Ecol 330:55-80

> Cruzado A, Velásquez Z, Pérez Mad C, Bahamón N, Grimaldo NS, Ridolfi F (2002) Nutrient fluxes from the Ebro River and subsequent across-shelf dispersion. Cont Shelf Res 22:349-360

Dempster T, Sanchez-Jerez P, Bayle-Sempere JT, GiménezCasalduero F, Valle C (2002) Attraction of wild fish to sea-cage fish farms in the south-western Mediterranean Sea: spatial and short-term temporal variability. Mar Ecol Prog Ser 242:237-252

Dempster T, Fernandez-Jover D, Sanchez-Jerez P, Tuya F, Bayle-Sempere J, Boyra A, Haroun RJ (2005) Vertical variability of wild fish assemblages around sea-cage fish farms: implications for management. Mar Ecol Prog Ser 304:15-29

Dempster T, Sanchez-Jerez P, Tuya F, Fernandez-Jover D, Bayle-Sempere J, Boyra A, Haroun R (2006) Coastal aquaculture and conservation can work together. Mar Ecol Prog Ser 314:309-310

Dempster T, Uglem I, Sanchez-Jerez P, Fernandez-Jover D, Bayle-Sempere J, Nilsen R, Bjørn PA (2009) Coastal salmon farms attract large and persistent aggregations of wild fish: an ecosystem effect. Mar Ecol Prog Ser 385: $1-14$

> Dempster T, Sanchez-Jerez P, Uglem I, Bjørn PA (2010) Species-specific patterns of aggregation of wild fish around fish farms. Estuar Coast Shelf Sci 86:271-275

Dempster T, Sanchez-Jerez P, Fernandez-Jover D, BayleSempere J, Nilsen R, Bjørn PA, Uglem I (2011) Proxy measures of fitness suggest coastal fish farms can act as population sources and not ecological traps for wild gadoid fish. PLoS ONE 6:e15646 
Dufour V, Jouvenel JY, Galzin R (1995) Study of a Mediterranean reef fish assemblage. Comparisons of population distributions between depths in protected and unprotected areas over one decade. Aquat Living Resour 8: $17-25$

FAO (Food and Agriculture Organization of the United Nations) (2008) Fishery and aquaculture statistics. FAO, Rome

Fernandez-Jover D, Sanchez-Jerez P, Bayle-Sempere JT, Valle C, Dempster T (2008) Seasonal patterns and diets of wild fish assemblages associated with Mediterranean coastal fish farms. ICES J Mar Sci 65:1153-1160

> Fernandez-Jover D, Sanchez-Jerez P, Bayle-Sempere JT, Arechavala-Lopez P, Martinez-Rubio L, Jimenez JAL, Lopez FJM (2009) Coastal fish farms are settlement sites for juvenile fish. Mar Environ Res 68:89-96

Fernandez-Jover D, Martinez-Rubio L, Sanchez-Jerez P, Bayle-Sempere JT and others (2011) Waste feed from coastal fish farms: a trophic subsidy with compositional side-effects for wild gadoids. Estuar Coast Shelf Sci 91: 559-568

> Freedman D, Lane D (1983) A nonstochastic interpretation of reported significance levels. J Bus Econ Stat 1:292-298

García-Charton JA, Pérez-Ruzafa Á (1998) Correlation between habitat structure and a rocky reef fish assemblage in the southwest Mediterranean. PSZN I: Mar Ecol 19:111-128

> García-Charton JA, Pérez-Ruzafa Á (2001) Spatial pattern and the habitat structure of a Mediterranean rocky reef fish local assemblage. Mar Biol 138:917-934

Gordoa A (2009) Characterization of the infralittoral system along the north-east Spanish coast based on sport shorebased fishing tournament catches. Estuar Coast Shelf Sci 82:41-49

Gordoa A, Illas X, Cruzado A, Velásques Z (2008) Spatiotemporal patterns in the north-western Mediterranean from MERIS derived chlorophyll a concentration. ICES J Mar Sci 72:757-767

Gordoa A, Olivar MP, Arevalo R, Viñas J, Molí B, Illas X (2009) Determination of Atlantic bluefin tuna (Thunnus thynnus) spawning time within a transport cage in the western Mediterranean. ICES J Mar Sci 66:2205-2210

Halpern BS, Walbridge S, Selkoe KA, Kappel CV and others (2008) A global map of human impact on marine ecosystems. Science 319:948-952

Karrer C (1986) Occurrence of the barrelfish, Hyperoglyphe perciformis (Teleostei, Perciformes, Stromateoidei) in the Mediterranean Sea and off Portugal. Cybium 10:77-83

Letourneur Y, Ruitton S, Sartoretto S (2003) Environmental and benthic habitat factors structuring the spatial distribution of a summer infralittoral fish assemblage in the north-western Mediterranean Sea. J Mar Biol Assoc UK
83:193-204

Lombarte A, Gordoa A, Whitfield A, James N, Tuset V (2012) Ecomorphological analysis as a complementary tool to detect changes in fish communities following major perturbations in two South African estuarine systems. Environ Biol Fishes (in press) doi:10.1007/s10641011-9966-0

- Lupatsch I, Katz T, Angel DL (2003) Assessment of the removal efficiency of fish farm effluents by grey mullets: a nutritional approach. Aquacult Res 34:1367-1377

Machias A, Giannoulaki M, Somarakis S, Maravelias CD and others (2006) Fish farming effects on local fisheries landings in oligotrophic seas. Aquaculture 261:809-816

Maurstad A, Dale T, Bjørn P (2007) You wouldn't spawn in a septic tank, would you? Hum Ecol 35:601-610

Morey G, Moranta J, Massutí E, Grau A, Linde M, Riera F, Morales-Nin B (2003) Weight-length relationships of littoral to lower slope fishes from the western Mediterranean. Fish Res 62:89-96

Oakes CT, Pondella DJ II. (2009) The Value of a net-cage as a fish aggregating device in Southern California. J World Aquacult Soc 40:1-21

> Rooker JR, Alvarado Bremer JR, Block BA, Dewar H and others (2007) Life history and stock structure of Atlantic bluefin tuna (Thunnus thynnus). Rev Fish Sci 15:265-310

Šegvić Bubić T, Grubišić L, Tičina V, Katavić I (2011) Temporal and spatial variability of pelagic wild fish assemblages around Atlantic bluefin tuna (Thunnus thynnus) farms in the eastern Adriatic Sea. J Fish Biol 78:78-97

> Sudirman, Halide H, Jompa J, Zulfikar, Iswahyudin, McKinnon AD (2009) Wild fish associated with tropical sea cage aquaculture in South Sulawesi, Indonesia. Aquaculture 286:233-239

Thresher R, Gunn J (1986) Comparative analysis of visual census techniques for highly mobile, reef-associated piscivores (Carangidae). Environ Biol Fishes 17:93-116

Tuya F, Sanchez-Jerez P, Dempster T, Boyra A, Haroun RJ (2006) Changes in demersal wild fish aggregations beneath a sea-cage fish farm after the cessation of farming. J Fish Biol 69:682-697

Valle C, Bayle-Sempere JT, Dempster T, Sanchez-Jerez P, Giménez-Casalduero F (2007) Temporal variability of wild fish assemblages associated with a sea-cage fish farm in the south-western Mediterranean Sea. Estuar Coast Shelf Sci 72:299-307

Vassallo P, Doglioli AM, Rinaldi F, Beiso I (2006) Determination of physical behaviour of feed pellets in Mediterranean water. Aquacult Res 37:119-126

Vita R, Marin A, Madrid JA, Jiménez-Brinquis B, Cesar A, Marin-Guirao L (2004) Effects of wild fishes on waste exportation from a Mediterranean fish farm. Mar Ecol Prog Ser 277:253-261 
Appendix 1. All species recorded at different stations, depths and seasons at an SB farm and an ABT farm in Spain, summer 2010 to spring 2011. C: cage, B: border, L: limit; D: deep water, M: midwater, S: surface; SU: summer, AU: autumn, WI: winter, SP: spring. $+, \Delta, \bullet$ : presence of a species



Editorial responsibility: Tim Dempster, Trondheim, Norway
Submitted: March 9, 2012; Accepted: May 16, 2012

Proofs received from author(s): June 16, 2012 